\title{
Mutầwầsith
}

JURNAL HUKUM ISLAM

\section{RUMUSAN PENDIDIKAN TENTANG HUKUM ISLAM DAN HUKUM \\ ADAT}

\author{
Rudi Hartono \\ Sekolah Tinggi Ilmu Tarbiyah (STIT) Al-Khairiyah Cilegon, \\ Indonesia \\ Email: kalamrudy@gmail.com \\ Abstrak
}

\begin{abstract}
Dalam rumusan pendidikan tentang hukum, utamunya hukum Islam termasuk juga hukum kawarisan di Indonesia, terjadi perdebatan sengit antara para ahli hukum mengenai status hukum adat. Karena itu, timbul 3 (tiga) mengenai hubungan hukum Islam dengan hukum adat, yaitu: teori receptio a contrario in complexu, dan teori receptie. Berlakunya hukum kewarisan Islam di Indonesia bukan melalui teori receptio in complexu dan teori receptie melainkan hukum kewarisan Islam yang berlaku karena kedudukan hukum Islam itu sendiri. Selain teori receptio a contrario yang disebutkan di atas, juga digunakan rumusan-rumusan garis hukum di dalam perundang-undangan dan Komplisai Hukum Islam, Qur'an Hadits Rasulullah, dan pendapat para sahabat Rasulujllah serta ahli hukum Islam.

Kata Kunci: adat, hukum, islam, waris
\end{abstract}

\begin{abstract}
In the formulation of education about law, especially Islamic law, including maritime law in Indonesia, there was a fierce debate between legal experts about the status of customary law. Therefore, three (3) arise regarding the relationship of Islamic law with customary law, namely: the theory of receptio a contrario in complexu, and receptie theory. The validity of Islamic inheritance law in Indonesia is not through the theory of receptio in complexu and the theory of receptie but the Islamic inheritance law that applies because of the position of Islamic law itself. In addition to the theory of receptio a contrario mentioned above, the formulation of legal lines is also used in the laws and compilations of Islamic law, the Qur'an's Hadith of the Prophet, and the opinions of the Companions of the Prophet and Islamic legal experts

Keywords: customary, law, islam
\end{abstract}




\section{PENDAHULUAN}

Hukum waris Islam telah berjalan ditengah-tengah masyarakat Islam Indonesia. Pada tahun 1992, pemerintah Belanda membuat sebuah komisi untuk meninjau kembali wewenang Priesterraad atau Raad Agama di Jawa dan Madura. Sebelum itu, yakni pada tahun 1882 secara resmi menurut hukum ketatanegaraan Hindia Belanda Pengadilan Agama Berwenang mengadili perkara kwearisan orang-orang Islam menurut ketentuan hukum Islam. (Ali, 2005:100) namun sesudah tahun 1937 berdasarkan statsbald 1937 No. 166 perselisishan tentang waris dipindahkan dari pengadilan Agama ke Pengadilan negri dengan menggunakan hukuman adat. Sedangkan diluar Jawa dan Madura tetap menjadi wewenang Pengadilan Agama sepanjang hukum waris Islam telah hidup terlebih dahulu dalam masyarakat. Dengan demikian hukum waris yang berlaku bagi umat Islam di Indonesia adalah hukum waris adat dan hukum waris Islam.

Sebelum bangsa Indonesia memperoleh kemerdekaannya kembali, di Indonesia dikenal serta berlaku aneka ragam hukum waris. Kitab-kitab hukum yang menjadi pegangan pada saat itu sudah ada. Menurut Moh Daud Ali yang dikutip oleh (Ali, 2005:98). Kitab hukum yang menjadi pegangan seperti kitab sabilil Muhtadin yaitu suatu kitab yang menyelesaikan sengketa antara umat Islam di daerah kesultanan Banjar. Demikian juga di daerah kesultanan Palembang, Banten, Demak, Jepara, Tuban, Gresik, Ngampel, dan Mataram terdapat kitab hukum Islam yang dijadikan pegangan oleh umat Islam dalam menyelesaikan berbagai masalah dalam hidup dan kehidupan mereka. Ini dapat dibuktikan dari karya-karya pujangga yang hidup pada masa itu. Misalnya, Kutaragama, Negara pada masa penjajahan sebagai berikut:

Bagi warga Negara golongan Indonesia asli berlaku hukum adat. Terdapt perbedaan hukum waris antara suatu daerah dengan 
daerah lainnya yang disebabkan adanya perbedaan sistem keturunan. Hukum waris adat di daerah yang sistem keturunannya Patrilinial berbeda dengan daerah yang sistem keturunannya Matrilinila dan berbeda dengan daerah yang yang sistem keturunannya Parental (Bilateral). Khsusu bagi warga Negara Indonesia asli yang beragama Islam berlaku dualisme hukum waris, yaitu hukum waris adat dan hukum waris Islam. Bagi golonga Timur Asing bukan Tioanghoa berlaku hukuman waris adatnya masingmasing. Bagi golongan Tionghoa dan Eropa berlaku hukum waris dari BW II title 12 sampai dengan 18 pasal 830 sampai dengan 1130

Dengan menganut Negara Hukum, yang demokratis, menurut penuturan Fazlur Rahman sesuai dengan sila "kerakyatan yang dipimpin oleh hikmat kebijaksanaan dalam permusyawaratan dan perwakilan", karena "Bangsa Indonesia" berwatak demokratis, maka penafsiran Islam yang betul-betul demokratislah yang akan berhasil, (Amal, 1990:15) dengan pijakan semangat dan jiwa alQur'an dan Sunnah Rasul, supaya memberikan keleluasan pemahaman dari yang harfiah, (Amal, 1990:15) sehingga forum demokrasi ijtihad kolektif maupun individu dalam Islam selalu relevan dengan segala keadaan yang berubah, dan menjadi trobosan maupun alternatif jawaban realitas sosial dan hukum menjadi hukum, sekarang dalam perspektif (mengantisipasi) yang berporos kepada sumbernya, yang pernah dilakukan umat Islam yang mula-mula (pada masa awal) itu, karena dorongan dan petunjuk al-Qur'an lah, selama beberapa abad menjadi umat yang kreatif menurut Abdul Halim Mahmud. (Ma'arif, 1990:Viii)

\section{METODOLOGI PENELITIAN}

Menurut Ronny Hanitjo Soemitro penelitian hukum dapat dibedakan menjadi: penelitian hukum normatif atau penelitian hukum doktrinal, yaitu penelitian hukum yang mempergunakan data sekunder. Penelitian hukum empiris atau penelitian hukum 
sosiologis, yaitu penelitian hukum yang mempergunakan data primer. ${ }^{1}$ Metode pendekatan yang akan digunakan dalam penelitian adalah metode pendekatan juridis empiris, atau dengan kata lain disebut normatif empiris. Dalam sebuah buku karangan Profesor Abdul Kadir Muhammad, mengatakan bahwa: "Penelitian hukum normatif empiris (applied law research) adalah penelitian hukum mengenai pemberlakuan atau implementasi ketentuan hukum normatif (kodifikasi, undang-undang, atau kontrak) secara in action pada setiap peristiwa hukum tertentu yang terjadi dalam masyarakat. Implementasi secara in action tersebut merupakan fakta empiris dan berguna untuk mencapai tujuan yang telah ditentukan oleh negara atau oleh pihakpihak dalam kontrak. Implementasi secara in action diharapkan akan berlangsung secara sempurna apabila rumusan ketentuan hukum normatifnya jelas dan tegas serta lengkap. ${ }^{2}$ Sehubungan dengan metode penelitian yang digunakan tersebut penulis melakukannya dengan cara meneliti peraturan-peraturan perundang- undangan, teori-teori hukum dan pendapat-pendapat para sarjana hukum terkemuka yang merupakan data sekunder, kemudian dikaitkan dengan keadaan yang sebenarnya.

\section{PEMBAHASAN HASIL PENELITIAN}

\section{Pengertian Hukum Warisan dan Sistem Pewarisan Islam}

Jadi pengertian hukum waris Islam adalah segala harta benda yang ditinggalkan oleh orang yang telah meninggal dunia yang akan diwarisi oleh para ahli waris yang telah ditentukan syara' setelah diambil untuk biaya-biaya perawatan si mayit, melunasi

${ }^{1}$ Ronny Hanitijo Soemitro, Metodologi Penelitian Hukum dan Jurimetri, (Jakarta: Ghalia Indonesia, 1998), hlm. 10

2 Abdul Kadir Muhammad, Hukum dan Penelitian Hukum,(Bandung: PT. Citra Aditya Bakti, 2004), hlm. 134 
hutang-hutangnya dan melaksanakan wasiatnya jika ada dalam dalam hal pembagiannya telah ditentukan dalam al-Qur'an dan AsSunnah.

Islam mempunyai metode dan sistem pewarisan yang berbeda dengan sistem pewarisan adat dan sistem pewarisan BW, dimana sistem pewarisan Islam menggariskan maksud dan tujuan pewarisan tidak saja untuk kepentingan kedudukan pribadi tetapi lebi luas dari itu dalam pandangan sosial kemasyarakatan, memperhatikan kerabat lainnya yang tidak mampu atau miskin. Hal ini dinyatakan dalam Al-Qur'an Surat An-Nisa ayat 7 dan 8.

Dalam sistem individual hukum waris adat, belum ditentukan bagian yang pasti tentang bnayak sedikitnya bagian setiap ahli waris, akan tetapi sistem hukum waris Islam sudah ditentukan bagian masing-masing ahli waris dari harta yang ditinggalkan si mati, setelah dikeluarkan biaya-biaya perawtan, unutk melunasi hutang-hutangnya dan untuk melaksanakan wasiatnya jika ada. Hal tersebut lebih jelasnya dinyatakan dalam Al-Qur'an Surat AnNisa ayat 11, 12, dan 176.

Pewaris atau Mawaris ialah orang yang meninggal dunia atau mati, baik mati hakiki maupun mati hukumi dengan meninggalkan harta benda yang akan diwariskan kepada ahli warisnya.Mati hakimi ialah suatu kematian yang dinyatkan oleh putusan hakim atas dasar beberapa sebab, meskipun sesungguhnya ia belum mati sejati, seperti orang yang dinyatakan hilang. Ahli waris ialah orang yang akan mewarisi atau orang yang akan menerima harta peninggalan dari orang yang meninggal, lantran mempunyai sebab-sebab untuk mewarisi yang telah ditentukan oleh syara', seperti adanya ikatan perkawinan, hubungan darah dan hubungan hak perwalian dengan orang yang meninggal.Golongan ahli waris menurut hukum Islam terdiri dari laki-laki dan perempuan yang 
jumlah seluruhnya 25 orang, terdiri dari 15 orang laki-laki dan 10 orang perempuan.

Ahli waris laki-laki yang terdiri dari 15 orang adalah sebagai berikut: Anak laki-laki; cucu laki-laki dari anak laki-laki dan seterusnya ke bawah; ayah; kakek; saudar laki-laki se-ibu seayah; saudara laki-laki seayah; saudara laki-laki seibu; kemenakan lakilaki (anak laki-laki; kemenakan laki-laki; saudara ayah (paman) yang seibu dan seayah; saudara ayah (paman) yang seayah;anak paman yang se-ibu seayah; anak paman yang seayah; suami; orang lakilaki yang memerdekakannya.

Adapun ahli waris dari pihak perempuan terdiri dari 10 orang, yaitu: Anak perempuan; anak perempuan dari laki-laki dan seterusnya ke bawah berturut-turut dari jurusan laki-laki; ibu; nenek perempuan (ibunya ayah) dan seterusnya berturut-turut dari jurusan perempuan; nenek perempuan (ibunya ayah) dan seterusnya ke atas yang melalui jalur dari jurusan ayah 9 laki-laki; saudara perempuan yang se-ibu dan seayah; saudara perempuan yang seayah; saudara perempuan yang seibu;istri; orang perempuan yang memerdekakannya. (Anwar, 1981:21-22)

Dari 25 jumlah ahli waris tersebut di atas, dapat dibagi menjadi 2 golongan, yakni ahli waris dzawul furud dan ahli waris 'ashabah.Ahli waris dzawul furud ialah ahli waris yang mendapat bagian tertentu dalam Al-Qur'an dan As-Sunah, sedangkan ahli waris 'ashabah ialah ahli waris yang tidak tentu bagiannya. Ahli waris 'ashabah ini kalau sendirian tidak bersama-sama dengan ahli waris dzawir furud maka semua harta warisan menjadi kepunyaanya, sedangkan kalau bersama-sama dengan ahli waris dzawil furud maka bagiannya adalah sisa harta warisan setelah dikurangi bagian ahli waris dzawil furud dan kalau tidak ada sisanya sama sekali maka dengan sendirinya ahli waris ashabah tidak mendapatkan apa-apa. 
Di samping ahli waris dzawil furud dan ahli waris 'ashabah, terdapat pula ahli waris yang disebut dzwail arham, yaitu keluarga yang mempunyai hubungan darah dengan si mati selain orangorang di atas. Ahli waris dzawil furud arham tidak mempunyai bagian tertentu dalam Al-Qur'an.Dalam hal ini terdapat perbedaan pendapat antara para ulama. Menurut Imam Syafe'i dan Imam Malik dzawul arham tidak berhak mewarisi, yang berhak ialah ummat Islam, dengan alasan bahwa dalam soal waris pada dasarnya sesuatu ketentuan yang tidak dapat ditetapkan kecuali berdasarkan Al-Qur'an, Hadits atau Qiyash.

Sedangkan menurut Imam Hanafi, bahwa dzawul furud berhak mewarisi, atau lebih berhak dibandingkan dengan umat Islam lainnya, dengan alasan ayat Al-Qur'an ayat 75 dengan surat An-Nisa ayat 7. Adapun ahli waris dzawul furud arham, yaitu: Cucu dari anak perempuan; kemenakan dari (anak dari) saudara perempuan; kemenakan perempuan dari saudara laki-laki; paman se-ibu (suadara ayah se-ibu); paman dari pihak ibu (saudara ibu); bibi dari pihak ibu (saudara perempuan ibu); bibi dari pihak ayah (saudar perempuan ayah); kakek dari pihak ibu (ayahnya ibu); nenek (perempuan) dari pihak ayah atau pihak ibu (ibunya ayah/ibu); saudara sepupu perempuan (anak perempuan paman); kemenakan dari saudara laki-laki yang se-ibu.

\section{Harta warisan}

Harta warisan yang disbut juga Maurus atau tirkah yang menurut Drs. Fatchur Rahman adalah:

Apa-apa yang ditinggalkan oleh orang yang meninggal dunia yang dibenarkan oleh syari'at untuk dipusakai oleh para ahli waris." (Rahman, 1981:36) Apa-apa yang ditinggalkan oleh orang meninggal, meliputi: kebendaan dan sifat-sifat yang mempunyai nilai-nilai kebendaan; hak-hak kebendaan; hak-hak yang bukan 
kebendaan; benda-benda yang bersangkutan dengan hak orang lain (Rahman, 1981:36).

Jadi harta warisan menurut Islam mencakup segala apa yang ditinggalkn oleh si mati, baik berupa benda maupun hak-hak, baik hak-hak kebendaan maupun bukan hak-hak kebendaan yang akan diwariskan kepada para ahli waris setelah dikurangi ongkos-ongkos penguburan, membayar hutang-hutang jika ada dan melaksanakan wasiat pewaris sendiri jika ada yang bersangkutan dengan harta peninggalan dengan ketentuan tidak boleh melebihi sepertiga dari harta peninggalan.

\section{Ketentuan Bagian ahli Waris}

Ahli waris yang mendapat dua pertiga ada 4 (emapat) orang, yaitu: 2 orang anak perempuan atau lebih, dengan ketentuan bila merka tidak bersama-sama dengan mu'ashshibnya (orang yang menjadiakn 'ashobah); 2 orang cucu perempuan pancar laki-laki atau lebih, dengan ketentuan bila mereka tidak bersama-sama dengan anak perempuan kandung atau mu'ashshibnya; 2 orang saudari kandung atau lebih, dengan ketentuan mereka tidka bersam-sama dengan mu'ashshibnya; 2 orang saudari se-ayah atau lebih dengan ketentuan bila si mati tidak mempunyai anak perempuan kandung, atau cucu perempuan pancar laki-laki atau saudari kandung.

Ahli waris yang mendapat sepertiga ada 2 (dua) orang, yaitu: Ibu, dengan ketentuan bila ia tidak bersama-sama dengan far'u warits, laki-laki maupun perempuan-perempuan atau bila ia tidak bersama-sama dengan 2 orang saudar-saudari sekandung atau seayah atau se-ibu saja; dan anak-anak ibu (saudara se-ibu bagi si mati) laki-laki maupun perempuan atau tidak bersama-sama dengan ahlu waris laki-laki (seperti ayah dan kakek shahish). 
Ahli waris yang mendapat seperenam ada 7 (tujuh) orang, yaitu: ayah, dengan ketentuan bila ia bersama-sama dengan far'u warits laki-laki (yaitu anak laki-laki atau cucu laki-laki pancar lakilaki betapa rendah menurunnya); ibu, dengan ketentuan bila ia mewarisi bersama-sama dangan fur'u warits secara mutlak atau bersama-sama dengan dua orang tau lebih saudara-saudari secara mutlak; kakek shahih, bila ia mewarisi bersama-sama dengan fur'u warits laki-laki; nenenk shahih, bila ia tidak bersama-sama dengan ibu; saudara se-ibu, laki-laki maupun perempuan bial ia mewarisi bersama-sama dengan fur'u warits laki-laki maupun perempuan atau mewarisi bersama-sama dengan ashul warits laki-laki; cucu perempuan pancar laki-laki, bial ia mewarisi bersama-sama dengan dengan seorang anak perempuan kandung; dan seorang saudari se-ayah atau lebih, bila ia bersama-sama dengan saudari kandung.

Ahli waris yang mendapat seperdua ada 3 (tiga) orang, yaitu: seorang anak perempuan, dengan ketentuan bila ia tidak bersamasama dengan anak laki-laki yang menjadi mu'ashshibnya; seorang cucu perempuan pancar laki-laki, dengan ketentuan bila ia tidak bersama-sama dengan anak perempuan atau orang laki-lakiyang menjadi mu'ashshibnya; suami, bial ia tidak bersama-sama dengan far'u warits; seorang saudari kandung, bila ia tidak mewarisi bersama-sama dengan mu'ashshibnya; dan seorang suadari seayah, bila ia tidak bersama-sama dengan anak perempuan kandung, atau cucu perempuan pancar laki-laki atau saudara kandung.

Ahli waris yang mendapat seperempat ada 2 (dua) orang, yaitu: suami, dalam kedaan bila ia mewarisi bersama-sama dengan fur'u warits bagi si istri baik yang lahir dari perkawinannya dengan suami tersebut, maupun yang lahir dari perkawinannya dengan suami yang terdahulu; istri, dengan ketentuan bila ia tidak 
mewarisi bersma-sama dengan fur'u warits, baik yang lahir dari perkawianannya dengan istri itu sendiri, maupun yang lahir dari perkawinannya dengan istri yang terdahulu; dan ahli waris yang mendapat seperdelapan hanya seorang saja, yaitu: Istri, dalam ketentuan bila ia mewarisi bersama-sama dengan fur'u waritd bagi suami, baik yang lahir dari perkawinannya dengan istri tersebut maupun lahir dari perkawianannya dengan istri terdahulu. (Rahman, 1981:128-130)

\section{Pengertian Hukum warisan dan Sistem Waris Adat}

Istilah waris di dalam kelengkapan istilah hukum waris adat diambil alih dari bahasa Arab yang menjadi bahasa Indonesia, dengan pengertian bahwa di dalam hukum waris adat tidak semata-mata hanya akan menguraikan tentang waris dalam hubungannya dengan ahli waris, tetapi lebih luas dari itu. (Hadikusuma, 19). Sehubungan dengan tidak adanya keseragaman pengertian di dalam hukum waris ini, dimana ada yang memakai istilah warisan, adapula yang memakai istilah hukum kewarisan dan ada juga hukum waris, maka di bawah ini akan dikemukakan beberapa pengertian istilah yang telah diutarakan oleh Hilman Hadikusuma, SH di dalam bukunya Hukum Waris Adat, diantaranya: Warisan: Istilah ini menunjukkan harta kekayaan dari pewaris yang telah wafat, baik harta itu telah dibagi atau masih dalam keadaan tidak terbagi-bagi. Istilah ini dipakai untuk membedakan dengan harta yang didapat seseorang bukan dari peninggalan pewaris tetapi didapat sebagai hasil usaha pencaharian sendiri di dalam ikatan perkawinan. Jadi warisan atau harta warisan adalah harta kekayaan seseorang yang telah wafat.

Peninggalan: Istilah ini menunjukkan harta warisan yang telah terbagi-bagi dikarenakan salah seorang pewaris masih hidup. Misalnya harta peniggalan ayah yang telah wafat tetapi masih dikuasai ibu yang masih hidup atau sebaliknya ibu yang telah wafat 
tetapi masih dikuasai ayah yang masih hidup. Termasuk di dalam harta peninggalan ini ialah harta pusaka.

Pusakah: Istilah ini yang lengkapnya disebut harta pusaka, dapat dibedakan anatara pusaka tinggi dengan pusaka rendah. Harta pusaka tinggi adalah harta peniggalan dari zaman leluhur, yang dikarenakan kedaannya, kedudukannya dan sifatnya tidak dapat atau tidak patut dan tidak pantas dibagi-bagi.

Sedangkan harta pusaka rendah adalah harta peninggalan dari beberapa generasi di atas ayah, misalnya harta peniggalan kakek atau nenek yang keduannya, kedudukannya dan sifatnya tidak mutlak yang tidak dapt dibagi-bagi, baik penguasaannya atau pemakainnya atau mungkin juga pemilikannya. Garis batas yang mana yang mana yang dinamakan pusaka tinggi dan pusaka rendah tidak dapat di tarik perbedaan yang tegas, tergantung dengan susunan kemasyarakatan adat bersangkutan.

\section{1) Pewaris}

Istilah ini dipakai untuk menunjukkan orang meneruskan harta peninggalan ketika hidupnya kepada waris atau orang yang setelah wafat meninggalkan harta peniggalan yang diteruskan atau dibagikan kepad ahli waris. Tegasnya pewaris adalah empunya harta peniggalan atau ampunya harta warisan.

2) Pewarisan

Istilah ini dipakai untuk menyatakan perbuatan menerusakn harta kekayaan yang akan ditinggalkan pewaris atau perbuatan melakukan pembagian harta warisan kepada para warisnya. Jadi ketika pewaris masih hidup pewarisan berarti penerusan atau penunjukkan, setelah pewaris berarti pembagian harta warisan.

3) Waris

Istilah ini dipakai untuk menunjukkan orang yang mendapat harta warisan, yang terdiri dari ahli waris yaitu mereka yang berhak menerima warisan atau bukan ahli waris tetapi kewarisan juga 
harta warisan.Jadi waris yang ahli waris ialah orang yang berhak mewarisi, sedangkan yang bukan ahli waris adalah orang yang kewarisan (Hadikusuma, 21-23) Unutk lebih jelasnya baiklah dikemukakan juga bagaimana pendapt-pendapat para ahli hukum adat mengenai pengertian hukum waris adat.

Berdasarkan pengertian yang telah dikemukakan oleh kedua ahli hukum adat tersebut, maka dapatlah diambil suatu pengertian bahwa hukum waris adat memuat ketentuan-ketentuan yang mengatur tentang cara penerusan dan peralihan harta kekayaan, baik yang berwujud maupun yang tidak berwujud dari pewaris kepada generasi berikutnya.

Cara penerusan dan peralihan harta kekayaan, menurut hukum adat dapat berlaku sejak pewaris masih hidup maupun setelah pewaris meninggal dunia. Menurut Hilman Hadikusuma, hukum waris adat itu mempunyai corak dan sifat-sifat tersendiri yang khas Indonesia yang berbeda dengan hukum Islam maupun hukum barat. Dimana letak perbedaanya terletak pada latar belakang alam fikiran bangsa Indonesia yang berfalsafah Pancasila dengan masyarakat yang bhineka tunggal ika. Latar belakang itu pada dasarnya adalah kehidupan bersama yang bersifat tolongmenolong guna mewujudkan kerukunan, keselarasan dan kedamaian di dalam hidup. (Hadikusuma, 19)

Sifat hukm waris adat berlainan dengan hukum waris Islam dan hukum waris barat yang sama-sama berlaku dalam tata hukum Indonesia, perbedaanya nampak jelas dalam harta warisan, ahli waris dan cara pembagiannya. Menurut halim Halim Hadikusuma, harta warisan adat tidak merupakan kesatuan yang dapat dinilai harganya, tetapi merupakan kesatuan yang tidak berbagi atau dapat dibagi menurut jenis macamnya dan kepentingan para warisnya. (Hadikusuma, 19) 
Selanjutnya beliau mengatakan bahwa harta warisan adat tidak boleh dijual sebagai kesatuan dan uang penjualan itu lalu dibagi-bagikan kepada para waris menurut ketentuannya yang berlaku. (Hadikusuma, 19). Dengan demikian harta warisan menurut hukum adat ada dua macam, yaitu harta warisan yang dapat dibagikan kepada ahli waris dan harta yang tidak dapat dibagikan kepada para ahli waris. Harta yang tidak dapat diwariskan secara perorangan kepada ahli waris adalah milik bersama para ahli waris yang dapat dipakai dan dinikmati bersama serta diambil manfaatnya.

Beberapa daerah di Indonesai, terdapat hukum waris adat yang hartanya diperoleh dari nenek moyang yang tidak dapat dibagi-bagikan pada masing-masing ahli waris, harta yang tidak terbagi adalah milik bersama para ahli waris yang diterimanya secara utuh, yaitu harta pusaka tinggi di Minangkabau, tanah dati di Hitu Ambon dan tanah kalakeran di Minahasa. Menurut Haliman Hadikusuma, harta warisan adat yang tidak terbagi, dapat digadaikan jika kedaan sangat mendesak berdasarkan pesetujuan para tua-tua adat dan para anggota kerabat bersangkutan. (Hadikusuma, 19).

Harta warisan yang tidak dapat dibagi-bagi ini, menurut Soerojo Wingjodipoero dapat dapat dibeda-bedakan sebagai berikut:

a) Karena sifatnya memang tidak memungkinkan untuk dibagi-bagi (misalnya barang-barang milik satu kerabat atau famili).

b) Karena kedudukan hukumnya memang terkait kepada satu tempat jabatan tertentu (misalnya barang-barang keramat kraton Kesepuhan Cirebon, seluruhnya tepat jatuh pada para ahli waris yang menjadi Sultan Sepuh serta barangbarang itu tetap disimpan di keraton Kesepuhan). 
c) Karena belum bebas dari kekuasaan persekutuan hukum yang bersangkutan, seperti tanah kasikepan didaerah Cirebon

d) Karena pembagiannya untuk sementara ditunda, seperti banyak dijumpai di jawa, misalnya apabila terdapt anakanak yang ditinggalkan masih belum dewasa, maka demi kepentingan janda beserta anak-anaknya supaya tetap mendapat nafkah unutk hidup terus, harta peninggalan tidak dibagi-bagi

e) Karena hanya diwarisi oleh seorang saja (sistem kewarisan mayoritas), sehingga tidak perlu dibagi-bagi. (Wignjodipoero, 1984:166)

Adapun harta warisan yang terbagi pada para ahli warisnya, menurut Haliman Hadikusuma, apabila si ahli waris tersebut akan menghilangkannya atau menjualnya, harus dimintakan pendapat diantara para anggota kerabat, agar tidak melanggar hak ketetanggaan (naastingsrecht) dalam kerukunan kekerabatan. (Hadikusuma, 19)Dengan demikian perbedaan hukum waris adat dengan hukum waris barat dan hukum waris Islam adalah sebagai berikut:

Hukum waris adat tidak mengenal asas "Legitime protie" atau bagian mutlak sebagaimana hukum waris Islam. Hukum waris adat tidak mengenal adanya hak bagi ahli waris untuk menuntut swaktu-waktu agar harta warisan dibagi-bgaikan, sebagaimana hukum waris barat dan hukum waris Islam merupakan suatu ketentuan bahwa apabila seorang meninggal dunia, maka agar segera dilakukan pembagian warisan agar yang meninggal dunia dapat tentram karena segal hutang-hutangnya telah terselesaikan, disamping agar tidak timmbul perselisihan dikemudian hari antara ahli waris. 
Meskipun menurut hukum waris adat tidak mengenal hak bagi ahli waris untuk menuntut sewaktu-waktu agar harta warisan dibagi-bagikan, namun menurut Halima Hadikusuma jika ahli waris mempunyai kebutuhan atau kepentingan maka ia dapat saja mengajukan permintaannya untuk dapat menggunakan harta warisan dengan cara musyawarah dan bermufakat dengan para waris lainnya. (Hadikusuma, 20)

\section{Sistem Pewarisan Adat}

Sebagaimana telah dikemukakan di atas, hukum waris adat adalah waris yang memuat garis-garis ketentuan yang berbedabeda antara daerah dengan daerah lainnya dalam sistem hukum warisnya sesuai dengan kedaan masyarakat Indonesia yang Bhineka yang mempunyai bentuk-bentuk kekerabatan dengan sistem keturunan yang berbeda-beda.Sistem keturunan yang berbeda-beda ini, nampak pengaruhnya dalam sistem pewarisan adat.Secara teoritis menurut Halima Hadikusuma sistem keturnan ada tiga macam, yaitu:

Sistem Patrilinial, yaitu sistem keturunan yang ditarik menurut garis bapak, dimana kedudukan pria lebih menonjol pengaruhnya dari kedudukan wanita di dalam pewarisan (gayo, Alas, batak, Nias, Lampung, Buru, Seram, Nusa Tengara, Irian). Sistem Matrilinial, yaitu sistem keturunan yang ditarik menurut garis Ibu, dimana kedudukan wanita lebih menonjol pengaruhnya dari kedudukan pria di dalam pewarisan (Minangkabau, enggono, Timor). Sistem Parental atau Bilateral, yautu sistem keturunan yang ditarik menurut garis orang tua, atau menurut garis dua sisi (bapak-ibu), dimana kedudukan pria dan wanita tidak dibedabedakan di dalam pewarisan (Aceh, Sumatra Timur, Riau, Jawa, Kalimantan, Sulawesi dan lain-lain) (Hadikusuma, 33)

Dalam masyarakat yang kekeluargaannya bersifat kebapakan, bila seorang perempuan kawin maka menurut 
Soerjono Soekanto mengakibatkan si istri tersebut masuk ke dalam clan keluarga suaminya. Sebagai konsekwensinya, anak-anak yang lahir dari perkawinan itu juga masuk ke dalam clan ayahnya. (Soekanto, 1983:264). Kekeluargaan yang bersifat keibuan, menurut Soerjono Soekanto bila terjadi suatu perkawinan, si sitri tetap tinggal dalam clan atau golongan familinya (keluarganya), sedangkan si suami tidak masuk ke dalam caln si istri, melainkan tetap tinggal dalam clannya sendiri. Si sumai diperkenankan bergaul dalam lingkungan kerabat si istri sebagai urang semendo (ipar). Anak-anak yang lahir dari perkawinan itu termasuk dalam caln ibunya. (Soekanto, 1983:267)

Dalam masyarakt yang menganut sistem kekeluargaan yang bersifat ke ibu bapakan, menurut Wirjono Projodikoro pada hakekatnya tidak ada perbedaan antara suami dan istri prihal kedudukannya dalam keluarga masing-masing. Bahkan dengan adanya perkawinan, masing-masing keluarga bertambah, baik keluarga suami maupun keluarga istri sebab disamping masingmasing tetap dalam lingkungan kekeluargaan semula, juga sudah dianggap menjadi keluarga pihak suami maupun istri. Dengan demikian anak-anak yang lahir dari perkawinan itu masuk dalam kekeluargaan ayah dan ibunya. (Prodjodikoro, 1983). Sistem kekeluargaan yang berbeda-beda ini, nampak sekali pengaruhnya dalam sistem pewarisan adat yang akan diuraikan di bawah ini. Menurut Halima Hadikusuma, sistem pewarisan adat tersebut dapat dibagi sebagai berikut:

a) Sistem pewarisan Individual

yaitu sistem pewarisan adat, dimana setiap ahli waris akan mendapat bagiannya msing-masing untuk dimiliki dan dikuasai sepenuhnya. Dengan pemilikan tersebut ia dapat mengusahakan, menikmati ataupun dialihkan kepada ahli waris lainnya, kerabat, tetangga, maupun orang lain. Sistem individual ini, banyak berlaku 
dikalangan masyarakat yang sistem kekeluargaanya bersifat bilateral, seperti di Jawa

b) Sistem pewarisan Kolektif,

Suatu sistem pewarisan yang mengandung kebersamaan dalam pemilikan dan penguasaan harta warisan yang ditinggalkan, dimana harta warisan ini merupakan kesatuan yang tidak terbagibagi penguasaan dan pemilikannya, melainkan setiap ahli waris berhak untuk mengusahakan, menggunakan atau untuk mendapatkan hasil dari harta peninggalan itu yang diatur bersama berdasarkan atas dasar musyawarah dan mufakat oleh semua anggota kerabat yang berhak atas harta peninggalan itu di bawah bimbingan kepala kerabat. Sistem pewarisan kolektif ini, misalnya dianut didaerah Minangkabau yang menganut sistem kekeluargaan matrilinial.

c) Sistem Pewarisan Mayorat

yaitu suatu sistem pewarisan yang sebenarnya sama dengan sistem pewarisan kolektip, hanya penerusan dan pengalihan hak penguasaan atas harta yang tidak terbagi-bagi itu dilimpahkan kepada anak tertentu yang bertugas sebagai pemimpin rumah tangga atau kepala keluarga yang menggantikan kedudukan ayah atau ibu yang sudah meninggal. Anak tertentu dalam kedudukannya sebagai penerus tanggung jawab orang tua yang meniggal berkewajiban mengurus dan memelihara saudarasaudara yang lain terutama bertanggung jawab atas harta warisan dan adik-adiknya yang masih kecil sampai mereka mereka dapat berumah tangga dan berdiri sendiri dalam suatu wadah kekerabatan yang turun temurun. Seperti di Bali, dimana terdapat hak mayorat anak laki-laki tertua dan ditanah Semendo Sumatra Selatan, dimana terdapat hak mayorat anak perempuan tertua (Hadikusuma, 34-38) 
Ketiga sistem pewarisan tersebut di atas, masing-masing tidak langsung menunjuk kepada suatu bentuk susunan masyarakat tertentu dalam sistem pewarisan itu berlaku. Namun sistem pewarisan tersebut dapat juga ditemukan dalam berbagai bentuk susunan masyarakat ataupun dalam suatu bentuk susunan masyarakat dapat pula dijumpai beberapa sistem pewarisan.

Dalam hal ini, Prof. Dr. Hazairin SH. Mengemukakan bahwa: sistem kewarisan yang individual bukan saja dapat dijumpai dalam masyarakat bilateral, tetapi juga dapat dijumpai dalam masyarakat patrilinial, seperti di Batak, malahan di Batak itu disana sini mungkin pula dijumpai sistem mayorat dan sistem kolektifp yang terbats demikian juga sistem mayorat (hak anak perempun yang tertua) itu, selain terdapat dalam masyarakat Patrilinila yang beralih-alih di tanah Semendo, dijumpai pula pada masyarakat bilateral orang Dayak di Kalimantan Barat, sedangkan sistem kolektif itu di dalam masyarakat bilateral, seperti di Minahasa sulawesi Uatara. (Hazairin, 1982:15)Sedangkan waris menurut BW dan sistem pewarisannya akan berbeda, sedikit penulis akan mambahas sekedar pengetahuan saja.

\section{Pengertian Hukum warisan dan Sistem Pewarisan BW}

Suruni Ahlan Syarif SH, hukum waris BW adalah hukum harta kekayaan yang dalam lingkungan keluarga karena karena wafatnya seseorang, maka akan ada pemindahan harta kekayaan yang ditinggalkan oleh si mati akibat dari pemindahan ini bagi orangorang yang memperolehnya baik dalam hubungan antara mereka maupun antara mereka dengan pihak ketiga (Syarif, 1983:15) Sedangkan menurut Prof. Subekti SH, hukum waris BW adalah mengatur hal ihwal tentang benda atau kekayaan seseorang jikalau ia meninggal. Juga dapat dikatakan bahwa hukum waris itu mengatur akibat-akibat keluarga terhadap harta peninggalan seseorang. (Subekti, 1980:17). 
Dengan demikian, hukum waris BW menurut garis-garis ketentuan yang mengatur tentang pemindahab harta kekayaan seseorang setelah meninggal dunia. Dalam hal mana pemindahan tersebut hanyalah hak-hak dan kewajiban-kewajiban dalam lapangan hukum kekayaan harta benda saja yang dapat diwariskan atau hanyalah hak-hak dan kewajiban-kewajiban yang dapat dinilai dangan uang.

\section{Sistem Pewaris BW}

Sistem pewarisan BW yang diatur dalam KUH Perdata, menurut Haliman Hadikusuma mengatur sistem pewarisan individual, dimana harta warisan harus selekas mungkin dibagikan kepada semua ahali waris setelah pewaris meninggal dunia. (Hadikusuma, 42)

Sandi pokok hukum waris BW menurut Wirjono Projodikoro adalah pasal 1066 KUH Perdata yang menyatakan bahwa:

a. Dalam hal seseorang mempunyai hak atas sebagian dari sekumpulan harta benda, seseorang itu tidak dipaksa memberikan harta benda itu tetap tidak dibagi-bagi diantara orang-orang yang bersama-sama berhak atasnya.

b. Pembagian harta benda ini selalu dapat dituntut, meskipun ada suatu perjanjian yang betentangan dengan itu.

c. Dapat diperjanjikan, bahwa pembagian harta benda itu dipertangguhkan selama waktu tertentu.

d. Perjanjian semacam ini hanya dapat berlaku selama lima tahun tetapi dapat diadakan lagi, kalau tenggang waktu lima tahun itu berlalu. (Prodjodikoro, 20)

Dari konsep diatas dapatlah diambil pengertian bahwa menurut hukum waris BW begitu pewaris meninggal dunia, harta warisan segera dibagi-bagikan kepada ahli waris. Para ahli waris mempunuai hak untuk menuntut agar harta waris segera dibagikan meskipun ada perjanjian yang bertentangan dengan itu, 
namun tidak menutup kemungkinan untuk menahan atau menangguhkan pembagian harta warisan tersebut karena adanya satu dan lain hal dapat berlaku atas persetujuan dan kesepakatan para hali waris. Akan tetapi penangguhan itu tidak boleh melebihi waktu lima tahun. bila waktu penangguhan itu sudah habis, tapi ada suatu hal dalam kedaan luar biasa, penagguhan itu dapat diperpanjang dengan suatu perjanjian baru.

\section{Pewarisan dan Ahli Waris}

Pewaris adalah setiap orang yang meninggal dunia dengan meninggalkan harta benda atau meninggalkan hak-hak dan kewajiban yang dapat dinilai dangan uang.Ahli waris adalah bedasarkan kedudukannya sendiri sebagai penerima warisan terhadap si meninggal. Misalnya seorang ayah meninggal, maka sekalian anak-anaknya tampil sebagai hali waris. Disamping ahli waris yang tampil dalam kedudukannya sendiri, KUH Perdata mengenal juga ahli waris dimana sebenarnya orang lain yang berhak atas sesuatu bagian warisan, tetapi orang itu telah meninggal lebih dulu dari pada orang yang meninggalkan warisan, yang disebut dengan "Bij Plaatsvervulling" artinya pergantian tempat (pasal 844 BW).

Adapun ahli waris yang berdasarkankedudukannya sendiri KUH Perdata menggolongkan sebagai berikut:

a. Golongan Pertama

Adalah anak-anak si mati beserta turunan-turunannya dalam garis lancang ke bawah, dengan tidak membedakan laki-laki atau perempuan dan dengan tidak membedakan urutan kelahirannya. Termasuk juga dalam golongan ini suami istri sebagaiman termaktub dalam pasal 852 KUH Perdata.

b. Golongan Kedua

Adalah orang tua dan saudara-saudara pewaris, dimana bagi orang tua disamakan dengan bagian saudara-saudara pewaris, 
namun ada jaminan bagi orang tua yang tidak kurang dari seperempat dari harta peninggalan, sebagaimana termaktub dalam pasal 854, 855 dan 856 KUH Perdata.

c. Golongan Ketiga

Adalah para anggota keluarga pihak ayah dan para anggota keluarga pihak ibu dalam hal tidak ada golongan pertama dan kedua. Dalam hal ini harta di bagi dua yang sama (kloving) dan masing-masing golongan ini mengadakan pembagian sendiri seolah-olah telah terbuka suatu warisan sendiri, namun tidak dimungkinkan terjadi suatu kali saja, sebagaimana termaktub dalam pasal 853 jo pasal 859 KUP Perdata.

d. Golongan Keempat

Adalah saudara / saudari se kakek buyut dan saudara / saudari si pewaris dalam garis simpang sampai derajat keenam.Disamping itu diluar perkawinan (anak zina) yang diakui anak sah, menurut KUH Perdata juga berhak mewarisi. Di dalam BW ada dua macam anak diluar perkawinan, yaitu anak alami yang diakui selaku anak dan anak alami yang tidak diakui. Diantara dua macam anak alami tersebut, maka anak alami yang diakui sebagai anak saja yang berhak mewarisi, sedangkan anak alami yang tidak diakui tidak berhak mewarisi.

\section{Harta Warisan}

Pada hakikatnya harta warisan yang diwarisi oleh ahli waris itu, menurut BW tidaklah hanya hal-hal yang bermanfaat saja bagimereka, melainkan juga hutang-hutang dari si peninggal warisan, dalam arti bahwa kewajiban membayar hutang-hutang itu pada hakekatnya beralih juga kepada para ahli waris.

Dalam pasal 833 BW ditentukan, bahwa para ahli waris dengan sendirinya sejak waktu wafatnya si peninggal warisan dianggap memiliki segala barang-barang, hak-hak dan piutang milik si wafat. Jadi seolah-olah para ahli waris melanjutkan 
kedudukan si wafat dalam masyarakat terhadap kekayaannya.Dengan demikian, hak-hak dan kewajiban-kewajiban si peninggal warisan mengenai kekayaannya sejak wafatnya dengan sendirinya beralih pada ahli waris.

\section{Ketentuan Bagian Ahli Waris}

a. Golongan I (pasal 852)

Yaitu terdiri dari anak beserta keturunannya dalam garis lurus ke bawah dengan tidak membedakan laki-lakai atau perempuan serta janda atau duda, maka harta warisan seluruhnya harus dibagi sebagai berikut : Apabila anak-anak dari si mati masih hidup, maka anak-anak itu serta janda mendapat masing-masing satu bagian yang sama, jadi apabila ada misalnya 4 anak dan janda, maka mereka masing-masing mendapat $1 / 5$ bagian.

Apabila salah seorang anak sudah meninggal lebih dahulu dan ia mempunyai anak (cucu dari si peninggal warisan), maka menurut pasal 842 BW cucu tersebut mendapat 1/5 bagian selaku pengganti ahli waris dari bapaknya yang meninggal lebih dahulu.

b. Golongan II (pasal 654 BW)

Apabila golongan ke I tidak ada, maka harta warisan berilah ke golongan ke II. Golongan ke II ini terdiri dari orang tua dan saudara-saudara kandung dari yang meninggal dunia.

Pembagian harta warisan untuk ahli waris dari golongan ke II ini, diatur dalam pasal 854, 855, dan pasal 856 BW.Menurut pasalpasal ini apabila ahli waris terdiri dari ayah, ibu dan beberapa saudara kandung dari si mati, maka mereka masing-masing menadapat bagian yang sama, akan tetapi bagian dari ayah dan ibu, masing-masing tidak boleh kurang dari $1 / 4$ bagian dari seluruh harta warisan.

Jadi kalau misalnya ahli waris terdiri dari ayah, ibu dan seorang suadara, maka mereka masing-masing mendapat 1/3 bagian. Apabila ad dua saudara, maka mereka masing-masing 
mendapat $1 / 4$ bagian dari sisinya $1 / 2$ bagian dibagi rata antara tuga saudara,maka masing-masing dari mereka mendapat $1 / 6$ bagian. Dalam pasal 855 BW disebutkan bahwa jika yang masih hidup hanya seorang bapak atau ibu saja, maka bagiannya adalah sebagai berikut:

1. $1 / 2$ bagian bila bersama-sama dengan seorang saudara

2. $1 / 3$ bagian bila bersama-sama dengan dua orang saudara

3. $1 / 4$ bagian bila bersama-sama dengan lebih dari dua orang saudara.

Dalam pasal 856 BW menjelaskan bahwa pembagian antara saudara -saudara adalah sama, kalau mereka itu mempunyai bapak ibu sama (sekandung). Jika mereka itu berasal dari lain perkawinan (bapak sama tapi lain ibu, ibu sama lain bapak) maka harta warisan dibagi dua. Bagian yang kesatu adalah bagian bagi garis bapak dan bagian yang ke dua adalah adalah bagian dari garis ibu.

Saudara-saudara yang mempunyai bapak dan ibu yang sama, mendapat bagian dari garis bapak. Saudara-saudara yang hanya se bapak saja atau hanya se ibu saja, mendapat bagian dari bagian bagi garis bapak atau bagi garis ibu saja.

c. Golongan III (pasal 853 dan pasal 859 BW)

Apabila golongan ke I dengan golongan ke II tidak ada, maka menurut pasal 853 dan pasal 859 BW harta warisan dibagi dua yang sama (kloving) dan masing-masing golongan ini mengadakan pembagian sendiri-sendiri seolah-olah telah terbuka suatu warisan sendiri. Bagian yang separoh diperuntukan bagi keluarga sedarah dalam garis bapak lurus keatas dan separoh bagian yang lain diperuntukkan bagi keluarga sedarah dalam garis ibu lurus ke atas. Ahli waris yang terdekat derajatnya dalam garis lurus ke atas mendapat $1 / 2$ bagian dari harta warisan. Kalau derajatnya sama, maka para ahli waris pada tiap garis mendapat bagian yang sama, 
kalau dalam satu garis ada keluarga yang terdekat, maka ia mengenyampingkan keluarga dengan derajat yang lebih jauh.

d. Golongan IV (pasal 858 ayat 2 BW).

Dalam pasal 858 ayat 2 di jelaskan bahwa apabila ahli waris dari golongan ke III tidak ada, maka tiap-tiap bagian separoh dari garis ayah atau dari ibu tadi jatuh pada saudara-saudara sepupu dari si mati, yaitu yang sekakek atau yang se-nenek dengan si mati (keluarga tingkat ke-4) secara sama rata.

Kalau inipun tidak ada, maka harta warisan jatuh pada sanak keluarga yang sekakek buyut atau senenek buyut dengan si mati (keluarga tingkat ke 6). Dalam pasal 861 BW diterangkan bahwa dalam garis menyimpang keluarga yang pertalian keluarganya berada dalam suatu derajat yang lebih tinggi dari derajat ke 6 tidak mendapat harta warisan. Kalau hal ini terjadi pada salah satu garis, maka bagian yang jatuh pada garis itu, menjadi haknya keluarga yang ada dalam garis yang lain, kalau ia mempunyai hak kekeluargaan dalam derajat yang tidak melebihi derajat ke 6 .

Dalam pasal 873 BW diterangkan bahwa kalau semua orang yang berhak mewarisi tidak ada lagi, maka seluruh harta warisan dapat dituntut oleh anak diluar kawin yang diakui. Dalam pasal 832 ayat 2 BW diterangkan bahwa apabila semua ahli waris seperti yang disebut diatas tidak ada lagi, maka seluruh harta warisan jatuh pada negara.

\section{SIMPULAN}

Hukum waris Islam adalah segala harta benda yang ditinggalkan oleh orang yang telah meninggal dunia yang akan diwarisi oleh para ahli waris yang telah ditentukan syara' setelah diambil untuk biaya-biaya perawatan si mayit, melunasi hutanghutangnya dan melaksanakan wasiatnya jika ada dalam dalam hal pembagiannya telah ditentukan dalam al-Qur'an dan As-Sunnah. 
Islam mempunyai metode dan sistem pewarisan yang berbeda dengan sistem pewarisan adat dan sistem pewarisan BW, Hal ini dinyatakan dalam Al-Qur'an Surat An-Nisa ayat 7 dan 8, 11, 12 dan 176.

Harta warisan adat cara penerusan dan peralihan harta kekayaan berlaku sejak pewaris masih hidup maupun setelah pewaris meninggal dunia. Harta warisan adatada dua macam, yaitu harta warisan yang dapat dibagikan kepada ahli waris dan harta yang tidak dapat dibagikan kepada para ahli waris. Perbedaan hukum waris adat, hukum waris barat dan hukum waris islam: Hukum waris adat tidak mengenal asas "Legitime protie" atau bagian mutlak sebagaimana hukum waris Islam. Hukum waris adat tidak mengenal adanya hak bagi ahli waris untuk menuntut swaktu-waktu agar harta warisan dibagi-bgaikan, sebagaimana hukum waris barat dan hukum waris Islam merupakan suatu ketentuan bahwa apabila seorang meninggal dunia, maka agar segera dilakukan pembagian warisan agar yang meninggal dunia dapat tentram karena segal hutang-hutangnya telah terselesaikan, disamping agar tidak timmbul perselisihan dikemudian hari antara ahli waris.

Sistem pewaris BW bahwa menurut hukum waris BW begitu pewaris meninggal dunia, harta warisan segera dibagi-bagikan kepada ahli waris. Para ahli waris mempunuai hak untuk menuntut agar harta waris segera dibagikan meskipun ada perjanjian yang bertentangan dengan itu, namun tidak menutup kemungkinan untuk menahan atau menangguhkan pembagian harta warisan tersebut karena adanya satu dan lain hal dapat berlaku atas persetujuan dan kesepakatan para hali waris. Akan tetapi penangguhan itu tidak boleh melebihi waktu lima tahun. bila waktu penangguhan itu sudah habis, tapi ada suatu hal dalam 
kedaan luar biasa, penagguhan itu dapat diperpanjang dengan suatu perjanjian baru.

\section{DAFTAR PUSTAKA}

A. Hassan. 1990. Al-Fara'id. Surabaya: Pustaka Progresif

A. Syafii Ma'arif et al.1990.Alquran dan Tantangan Modernitas. Yogyakarta: Sipress

Fatchur Rahman. 1981. IImu Waris.Bandung: PT. Almaarif

Moh. Anwar Bc. Hk. 1981. Hukum Waris dalam Islam dan MasalahMasalahnya. Surabaya: Al-Ikhlas

Halim Hadikusuma. 1980. Hukum Waris Adat. Bandung: Alumni Moh Anwar, "Hukum waris dalam Islam dan masalah masalahmya" Soerjono Soekanto. Sleman B.1983. Taneko. Hukum Adat Indonesia. Jakarta: Rajawali

Hazairin. 1982. Hukum Waris Bilateral Menurut Al-Qur'an dan Hadits. Jakarta: Tintamas

Soepomo.1984. Bab-Bab Tentang Hukum Adat. Jakarta: Pradya Pramita

Wirjono Prodjidikoro. 1983. Hukum Warisan d Indonesia. Bandung: Sumur

Prof. Subekti SH. 1980. Pokok-Pokok Hukum Perdata. Jakarta: Intermas

Soserojo Wignjodipoero. 1984. Pengantar dan Asas-Asas dan Hukum Adat. Jakarta: Gunung Agung

Suparman Usman. 2002. Hukum Islam.Jakarta: Gaya Media Pratama

Surini Ahlan Syarif. 1983. Intisari Hukum Waris Menurut Burgelijk Wetboek. Jakarta: Ghalia Indonesia

Taufik Adnan Amal. 1990. Islam dan Tantangan Moderinitas. Bandung: Mizan

Zainuddin Ali. 2005. Hukum Islam: Pengantar Ilmu Hukum Islam di Indonesia. Palu:YAMIBA 